\title{
Savjest kao Božji dar čovjeku u kontekstu kulture života
}

\author{
SuzANA VULETIĆ* \\ • https://doi.org/10.31823/d.27.4.2 • \\ UDK: $27-42^{*} 179^{*} 61 \cdot$ Izvorni znanstveni rad \\ Primljeno: 23. veljače 2018. • Prihvaćeno: 2. prosinca 2019.
}

${ }^{*}$ izv. prof. dr. sc.

Suzana Vuletić, Katolički

bogoslovni fakultet u

Đakovu Sveučilišta Josipa

Jurja Strossmayera u

Osijeku, P. Preradovića 17,

p. p. 54,31400

Đakovo, Hrvatska, suzanavuletic007@ gmail.com

Sažetak: Savjest igra veliku ulogu u moralnom održavanju osobnoga, vjernickoga i profesionalnoga života. Biti savjestan u darovanoj slobodi djelovanja i moralne odgovornosti opredijeljenosti za ispravno postupanje u konformističkom društvu u kojem prevladavaju pluralistička (bio)etička uvjerenja, izlaže nas pred mnoštvo egzistencijalnih borbi u ustrajnosti savjesnoga postupanja. To se posebno očituje u primjeni brojnih znanstvenih dostignuća u kliničkoj praksi, koja otvara prostor za konfliktne situacije, sudjelovanjem u znanstvenim istraživanjima, dijagnostičkim i terapijskim postupcima i zahvatima koji nisu u skladus moralnom savješću pojedinca, gdje se međusobno suprotstavljaju pragmatični ciljevi s medicinskom etikom, zaštitom ljudskih prava i dostojanstva života, što posljedično zahtijeva očuvanje savjesne opredijeljenosti prizivom savjesti. Da bi apel na priziv savjesti bio moralno utemeljen, potrebno je podrobnije se upoznati s etimološkim i moralnim određenjem savjesti u kontekstu teološkoga nauka, poštovati biopravne odrednice u etickim $i$ strukovno-profesionalnim načelima koji afirmiraju slobodu misljenja, savjesti i vjeroispovijesti kao temeljna ljudska prava, zajamčena medunarodnim dokumentima i kodeksima medicinske etike i deontologije. Njihovim se udruženim inicijativama podupire moralna odgovornost savjesnoga postupanja koja iziskuje poštovanje dostojanstva, nepovredivosti i svetosti ljudskoga života, koji posebno dolaze do izražaja u perspektivi kršćanske antropologije, moralne teologije i personalističke bioetike.

Ključne riječi: savjest, naravni zakon, oblikovanje savjesti, priziv savjesti, kršćanska antropologija, moralna teologija, personalistička bioetika, dostojanstvo, vrijednost/nepovredivost/svetost života. 


\section{Uvod}

U životu nema ljepše pohvale čovjeku od one da je savjestan. Savjestan u svom postojanju i radu.

No biti savjestan u darovanoj slobodi djelovanja i moralne odgovornosti opredijeljenosti za ispravno postupanje u konformističkom društvu u kojem prevladavaju pluralistička (bio)etička uvjerenja izlaže nas pred mnoštvo egzistencijalnih borbi u ustrajnosti savjesnoga postupanja.

Moralni teolog i nadbiskup u miru M. Srakić smatra da su danas $\gg$ ljudi nesigurni u svojim odlukama savjesti. Nesigurni su u njenu ispravnost, ne znaju jesu li dobro shvatili normu, čak ni to je li i sama norma u sebi sigurna; nesigurni su poznaju li dovoljno ispravno i vrednuju stvarnu situaciju i svoju moralnu obvezu... Sva ta nesigurnost velikim dijelom ovisi o psihofizičkim uvjetima i dinamizmima, unutrašnjim prisilama, psihološkim kompleksima i podsvjesnim motivima što nastaju iz raznih težnji koje se bude iz represija na spolnom, društvenom, duhovnom i drugim područjima $\ll .^{1}$

Posljedično tomu T. Ivančić upozorava da »kad nestaje sklad sa svojom savješću, čovjek se umjesto ljepoti, klanja kiču i patvorini; umjesto istine poluistini, umjesto dobroti glumi, umjesto slobodi podložnosti strastima i požudama, umjesto dobrote izražavanju ružnoće, umjesto moralnosti nemoral, umjesto humanosti mržnju, umjesto istine laž . $^{2}$

Ipak, neovisno o vremenu, kulturi i vjerskom uvjerenju, ideološkoj ili etičkoj opredijeljenosti, političkom zastupanju i/ili pravnom dopuštenju, čovjek je oduvijek u sebi osjećao glas savjesti.

Savjest igra veliku ulogu u moralnom održavanju našega života, pa tako i u bioetičkom i kliničkom kontekstu. Ljudi osluškuju svoju savjest, odgajaju je i slijede u svom svakodnevnom životnom, osobnoj i profesionalnoj opredijeljenosti.

Ona je poput ugrađene navigacije. Vodi nas na nesigurnim putovima života. Ispravlja ako skrenemo..., vraća na pravi put ako zalutamo...

Upravo nam je jedan takav siguran oslonac potreban u dezorijentiranosti suvremenoga društva, gdje nedostaje čvrstih moralnih i etičkih uporišta, jer današnji mentalitet liberalnoga subjektivizma afirmira individualnu slobodu osobne savjesti, lišene njezina metafizičkoga utemeljenja.

\footnotetext{
${ }^{1}$ M. SRAKIĆ, Odgovornost za vlastitu savjest, u: Vjesnik Đakovačko-osječke nadbiskupije i Srijemske biskupije 134(2006.)3, 202-203., 202.

${ }^{2}$ T. IVANČIĆ, Dijagnoza duše i hagioterapija, Zagreb, ${ }^{8}$ 2015., 229.
} 
Samim tim čini se da u našem društvu božanski zakon gubi važnost pred civilnim, dok ta ista civilna legislativa ne vrijedi jednako za sve.

Ta izjava posebno zabrinjava u kontekstu profesionalnoga djelovanja, gdje se do nedavno rijetko koji pojedinac suočavao s tolikim profesionalnim konfliktima lojalnosti između svoje savjesti i radne etike. Njezini su kodeksi redovito balansirali u harmoniji općedruštvenih vrijednosti, univerzalnih etičkih normi, stručne deontologije i distributivnoga prava.

Međutim u recentnije vrijeme situacija se drastično promijenila.

Tehnološkom transformacijom suvremenoga znanstvenoga progresa nailazimo na sve učestalije primjere laksativne savjesti koja se bez imalo skrupula ne oslanja više ni na svoj, ni na civilni, ni na božanski glas.

Najdramatičniji odraz primjećuje se u biomedicinskoj domeni.

»Primjena novih spoznaja u kliničkoj praksi otvara prostor za mnogobrojne konfliktne situacije gdje se međusobno suprotstavljaju ciljevi istraživanja s medicinskom etikom, zaštitom ljudskih prava i dostojanstva života, sudjelovanjem u znanstvenim istraživanjima, dijagnostičkim i terapijskim postupcima i zahvatima koji nisu u skladu sa savješću pojedinca. $\ll^{3}$ Napose određenim biomedicinskim zahtjevima pružanja usluga poput pobačaja, propisivanja i/ili izdavanja kontraceptiva/ interceptiva/kontragestativa, sterilizacije, sudjelovanja u potpomognutoj oplodnji, eksperimentiranju s fetusima, neetičnom ophođenju s humanim biološkim materijalom, eugeničkim alteracijama genoma, kloniranja, genomske hibridizacije, genotipske selekcije, nemoralnim postupcima i ishodima invazivne prenatalne dijagnostike, predimplantacijske manipulacije, transfuzije krvi, komercijalne transplantacije, cyborgizirajuće medicine, određenih cijepljenja, eutanazije, palijativne sedacije i brojnih drugih.

U bolničkom se dušobrižništvu neminovno susrećemo sa sve učestalijim medijskim progonom i stigmatizacijom onih koji se u svom profesionalnom djelovanju nađu u konfliktu s njihovim temeljnim moralnim uvjerenjem, te se pozovu na priziv savjesti. ${ }^{4} \gg$ Svjedoci smo da se nad suvremenim čovjekom na različite načine provodi sustavno utišavanje glasa savjesti, sve do njezinoga otupljivanja i potpunog umrtvljenja. Pravnim se propisima pokušava stvoriti neku umjetnu savjest kojom

${ }^{3} \mathrm{~J}$. ČIZMIĆ, Pravo zdravstvenih radnika na »priziv savjesti«, u: Zbornik Pravnog fakulteta Sveučilišta u Rijeci 37(2016.) 1, 753-786., 764.

${ }^{4}$ Za podrobniji pristup vidi: M. RADAN, S. VULETIĆ, Mogućnost priziva savjesti u medicini iz perspektive kršćanskog liječnika, u: Vjesnik Đakovačko-osječke nadbiskupije i Srijemske biskupije 145(2017.)2, 28-32. 
se nastoji opravdati grijeh protiv temeljnog zakona ljubavi $\ll^{5}$, no i samih deontoloških dokumenata, kojim je zdravstveni djelatnik »dužan suzdržavati se od svake aktivnosti koja nije spojiva s ugledom, dostojanstvom i neovisnošću liječničkog zvanja. $\ll^{6}$

Ipak, unatoč mišljenju da živimo u društvu bez etike i morala, apel na objekciju savjesti toliko zastupljenoga visokoga postotka naših medicinskih djelatnika i katoličkih liječničkih udruženja svjedoči nam da nije tako i da se savjest nastoji slijediti. No, da bi njezin apel bio moralno utemeljen, potrebno je podrobnije se upoznati s njezinim etimološkim i teološkim odrednicama.

\section{Etimološko određenje savjesti}

Opće etimološko određenje savjesti susrećemo pod različitim poimanjima: svijest, spoznaja, shvaćanje, znanje, moralni osjećaj, odgovornost, unutarnje iskustvo, poštenje, bojazan. ${ }^{7}$ Najčešći pojam semitskih naroda jest leb tachor (čisto srce), dok se kod stoika savjest najčešće poima izrazima: logos, physis, aisthesis, utemeljujući filozofsko poimanje savjesti kao unutarnjega naravnoga zakona i mjerilom čovjekova djelovanja. Često se i pojam epikeje izjednačuje s terminom savjesti. Ona korigira zakon kao neka viša pravednost potičući čovjeka na humanu upotrebu zakona kada je on zbog svoje općenitosti nedostatan. ${ }^{8}$

Sociološka definicija određuje ju kao »mentalni proces koji nastoji očuvati individualnu autentičnost i integrativnost, upozoravajući individuu na potencijalno odstupanje od vrijednosti čina $\ll$. ${ }^{9}$

U psihologiji se na savjest referira prosudbama koje nemaju izravne povezanosti s moralnom istinom, već s osjećajima koji proizlaze od super-ega i svjesnosti socijalnih konvencija. Smatra se i: »složenom psihičkom instancom koja kreira, oblikuje, procjenjuje i vrednuje moralnu praksu našega ponašanja. Ona se može poimati i kao instancija subjektivne svijesti u kojoj je kodiran naš vrijednosni moralni sustav. Savjest je tako, složena psihička instanca koja sadržava elemente mišljenja, emotivnog $\mathrm{i}$ intuitivnog, dakle racionalnog i iracionalnog, uz njihovo međusobno djelo-

\footnotetext{
${ }^{5}$ Poruka za Dan života 2019. - Savjest u svjetlu zakona ljubavi. Dostupno na: http://hbk.hr/porukaza-dan-zivota-2019-savjest-u-svjetlu-zakona-ljubavi/ (25. 1. 2019.)

${ }^{6}$ Zakon o liječništvu, u: Narodne novine 121/03, 117/08., čl. 4.

${ }^{7}$ Usp. I. FUČEK, Moralno-duhovni život. Osoba-savjest, I, Split, ${ }^{2} 2006 ., 119$.

${ }^{8}$ Usp. M. BIŠKUP, Epikeja i oblikovanje savjesti, u: Bogoslovska smotra 2(1977.)3, 303-306., 301.

${ }^{9}$ N. T. MORTON, K. W. KIRKWOOD, Conscience and Conscientious Objection of Health Care. Professional Refocusing the Issuse, u: HEC Forum 21(2009.)4, 351-364., 352.
} 
vanje na nesvjesnoj i svjesnoj razini. $\ll^{10}$ Tako da se ona često divergentno smatra: pogrješivom (Broad), nepogrješivom (Butler); posljednjom uporišnom točkom emotivnoga (Mill) i/ili racionalnoga (Rashdall); glasom Božjim (Hartmann), glasom prilagodbe društvenim normama (Paulsen), savjetodavcem (Nowell-Smith), internom komandom (Mayo), svjesnim nutarnjim počelom (Butler), nesvjesnim unutarnjim predodređenjem za djelovanje (Freud), predispozicijom za određeno uvjerenje (Wand), ekspresijom nutarnjih vrijednosti, motivacijom, intuicijom koja nas upozorava na dobro i zlo, lokusom moralnoga znanja, humanom krjepošću (Emerson-Daar), pregovaračem osobnoga integriteta i profesionalnih vrijednosti (Night), sredstvom utoka moralnoj drami između pacijenta i liječnika (Barfield), sredstvom poznavanja Božje volje (Lawrence - Curlin), dok Lock i Mill definiraju princip individualne vrhovne suverenosti u čovjekovoj savjesti kao izvor moralne autonomije. ${ }^{11}$

Filozofski pogled na savjest ističe njezinu dostojanstvenost kao »glas bitka $\ll$ i »utemeljenje same čovječnosti« (Scheler, Hartmann, Heidegger, Jaspers). Njezina snažna afirmacija iščitava se kod Kanta koji pravi zaokret od puko metafizičkoga značenja prema bitno etičkom značenju svojom poznatom tvrdnjom: »Dvije stvari ispunjavaju me sve većim strahopoštovanjem i udivljenjem - zvjezdano nebo nada mnom i moralni zakon u meni.« Kant ističe savjest kao »glas unutarnjeg zakona kojega čovjek samom sebi ne daje, već ga otkriva u sebi«, argumentirajući da ljudska bića, slobodna i racionalna, upravljaju sama sobom i kao takva trebaju biti vođena univerzalnim moralnim zakonom u formi kategoričkoga imperativa na temelju kojega trebamo djelovati. Nadalje argumentira da se upravo čovjekovo dostojanstvo ističe u moralnosti savjesnoga djelovanja. »Moralnost je uvjet pod kojim umno biće jedino može biti svrha sama po sebi, jer je samo s pomoću moralnosti moguće da netko bude zakonodavan član u carstvu svrha. ${ }^{12}$

Antropološko poimanje promatra savjest osnovanu na bitku (Eckhardt), kao nešto što je »položeno u osobu « (Buber) i ono što $\gg$ određuje što ona treba postati $\ll$. Fromm ističe da je humanistička savjest $\gg$ spoznaja samog sebe $\ll i \gg z n a n j e ~ o ~ n a j v i-$ šem cilju «. Čovjek ide prema tom cilju i u skladu je sa svojim bitkom kada se trudi oko krjeposti i vrlina. One su »odgovornost prema egzistenciji $\ll$, te se čovjek u njima osjeća sigurnim, sretnim i mirnim. Takva humanistička savjest, zasnovana na

\footnotetext{
${ }^{10}$ N. ZURAK, Savjest i priziv savjesti u medicinskoj znanosti i u liječničkoj praksi, u: Ž. ZNIDARČIĆ (ur.), Etika u medicinskoj znanosti, Zagreb, 2009., 99-100.

${ }^{11}$ Usp. J. MACLURE, C. TAYLOR, Secularism and freedom of conscience, Cambridge - Massachusetts - London, 2011., 10.

${ }^{12}$ I. KANT, Utemeljenje metafizike ćudoređa, Zagreb, 2016., 171-172.
} 
bitku, u suglasju je s cijelim čovjekovim bićem i osjećajem čovjekove ljubavi prema sebi i drugima, što predstavlja ispunjenje smisla života.

Moralno određenje savjesti naglašava da se bitna dinamika savjesti ne može objasniti isključivo na temelju same naravi razuma i volje (ako ih promatramo odvojeno), već na temelju njihova sjedinjenja u dubini duše i sličnosti s Bogom (Häring). ${ }^{13}$ Ona predstavlja onaj privilegirani prostor slobode koji čovjeku nitko ne može oduzeti, osim ako ga se sam ne odrekne. Ona je mjesto gdje se čovjek susreće s Istinom i onda kada je želi izbjeći. ${ }^{14}$ Tako nitko ne može do kraja zanemariti moralni zakon što ga je sam Bog upisao u naša srca.

Kršćani trebaju slijediti svoju savjest onako kako ih poučava sveta doktrina Crkve, sukladno njihovu razumu, prosvijećenom vjerom, prema prosudbi ispravnih vrijednosti. Stoga je nužno savjest cjelovitije promatrati u kontekstu biblijsko-teološkoga nauka.

\section{Biblijsko-teološki nauk o moralnoj savjesti}

U Svetom pismu savjest se prikazuje situirana $\mathrm{u} \gg \mathrm{srcu} \ll / \gg$ bubrezima $\ll$ ( Job 27, 6; Ps 16,7$)$, odražava Božji zakon u nama (Dt 6, 6-9; Ps 37, 31; 40, 9), prosvijetljena je božanskom mudrošću (Ps 90, 12) na temelju naravnoga zakona upisanoga u našu nutrinu. ${ }^{15}$ Savjest se identificira $\mathrm{s} \gg$ osjećajem za dobro koji je utisnuto u nas « (sv. Augustin), s »iskrom božanske ljubavi koja je skrivena u nama $\ll$ (sv. Pavao) i sa $\gg$ zakonom koji je upisan u srcu svakog od nas « (sv. Bazilije), »interior intimo meo $\ll, ~ \gg$ grande profundum $\ll$, $\gg$ scintilla animae $\ll$, $\gg$ zakonom našeg intelekta $\ll$, jer je to prosudba razuma izvedena iz prirodnoga prava. Savjest je prema tomu: skup mjerila, normi i kriterija kojima se vrjednuju namjeravani i/ili ostvareni čini kao moralno dobri ili loši. ${ }^{16}$

U Starom zavjetu srce (heb. leb, grč. kardia) je sinonim za savjest. Božji duh oblikuje to srce da djeluje po njegovoj volji (Ps 51, 12; Izr 22, 11; Pnz 30, 5-10). ${ }^{17}$ Upotre-

${ }^{13}$ Usp. B. HÄRING, Kristov zakon, I, Zagreb, 1973., 161.

${ }^{14}$ Usp. I. FUČEK, Osoba - savjest, 167.

${ }^{15}$ Usp. DRUGI VATIKANSKI KONCIL, Pastoralna konstitucija o Crkvi u suvremenom svijetu $\gg$ Gaudium et spes «, u: ISTI, Dokumenti, Zagreb, 1998. (= GS), br. 16; G. GRISEZ, Christian moral principles. The way of the Lord Jesus, I, Illinois, 1983., 73.

${ }^{16}$ Uloga savjesti jest u nastojanju da se etički opravda budući čin (ovdje govorimo o borbi, tj. konfliktima savjesti) i da moralno ocijeni već ostvareni čin (ako je osoba nešto činila po vlastitom uvjerenju koje je bilo prisutno prije čina, sam čin donijet će joj zadovoljstvo; no u protivnom će ju savjest kuditi, tj. imat će »grižnju « savjesti). Usp. K. KRSTIĆ, Savjest, u: V. FILIPOVIĆ (ur.), Filozofijski rječnik, Zagreb, 1984., 297.

${ }^{17}$ Usp. M. PERKOVIĆ, Temelji teološke etike, Sarajevo, 2002., 101-102. 
bljava se i izraz mudrost, koja dovodi do djela milosrđa, pravde, čistoće, strpljivosti i jakosti. ${ }^{18}$

U Novom zavjetu nalazimo pojmove: »dobra savjest « (1 Tim 1, 5.19; $1 \mathrm{Pt} 3$,

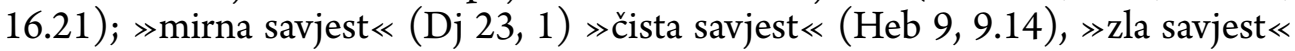
(Heb 10, 22), »okaljana savjest « (Tit 1, 15). ${ }^{19}$ Ona je prema tomu odjek Božje riječi u nama i u našem djelovanju, kao odraz osobnoga dijaloga čovjeka s Bogom i kao takva je temelj moralne odgovornosti jer čovjek po njoj sluša Božji glas i treba prema njemu uskladiti svoje djelovanje.

U patrističko vrijeme Oci iznose osjećaj radosti kao posljedicu čiste savjesti, obvezatnost suda savjesti, savjest kao unutrašnju čovjekovu moć po kojoj je Bog nazočan u duši i time je ona moralno mjerilo duše, ali i grižnju savjesti u slučajevima nemoralnoga postupanja. Savjest je stražar, nadzornik, svjedok, odvjetnik i sudac svih naših dobrih i zlih činova. Trajno je budna, hvali nas i kudi. ${ }^{20}$

Skolastika je razlikovala synderesis i conscientia. Synderesis je anamnesis/prva, ontološka razina savjesti kao pomoć izvana koja čini da dozrijeva naša unutarnja otvorenost istini. Stoga ju valja uvijek iznova pročišćavati i braniti od subjektivnosti i društvenih pritisaka. Conscisentia je druga razina savjesti koja se odnosi na prosudbu i odlučivanje. Sveti ju Toma opisuje kao nutarnju odbojnost prema zlu i usmjerenost na dobro. ${ }^{21}$ Prema tomističkom shvaćanju, cjelokupna moralna savjest promatra se kroz temeljnu savjest (lat. synderesis), moralno znanje (lat. scientia moralis) i moralnu savjest (lat. syneidesis). ${ }^{22} \mathrm{~B}$. Häring smatra da je savjest dinamična snaga i jednoga i drugoga i to kao nekakav međusoban utjecaj razuma, volje i cijele ljudske osobnosti, i psihe i duha. ${ }^{23}$

Na temelju toga savjest možemo definirati kao onu ljudsku sposobnost koja obznanjuje moralne dužnost i poziva nas da ih ostvarujemo. Moralne nam norme osiguravaju usmjerenost prema moralno dobrim odlukama koje vode istinskom samoostvarenju osobe. Ljudi tako žive odgovorno, suobličeni Božjemu zakonu, upisanom u njihovu narav.

\footnotetext{
${ }^{18}$ Usp. M. VIDAL, Kršćanska etika, Đakovo, 2001., 110.

${ }^{19}$ Usp. I. DUGANŽIĆ, Savjest - nepotkupljivi glas u čovjekovu srcu, u: Vjesnik Đakovačko-osječke nadbiskupije i Srijemske biskupije 134(2006.)3, 203-204., 204.

${ }^{20}$ Usp. I. FUČEK, Osoba-savjest, 140.

${ }^{21}$ Usp. TOMA AKVINSKI, Summa theologiae I, q. 79, a. 13; ISTI, De Ver, q. 17, a. 1.

${ }^{22}$ Usp. TOMA AKVINSKI, On Conscience, Disputed Questions on Truth 17, u: Thomas Aquinas selected writings, R. Mcinery (ur.), 221-a23, 1998., ISTI, The summa theologica of st. Thomas Aquinas, q. 79, at art. 13. Dostupno na: http://www.newadvent.org/summa (25. 1. 2019.)

${ }^{23}$ Usp. B. HÄRING, Liberi e fedeli in Cristo, I, Roma, 1979., 281.
} 
Daljnji nauk crkvenoga učiteljstva izoštrava diktat savjesti. Leon XIII. u svojoj enciklici Diuturnum (1881.) naglašava da je svrha civilnoga zakona vezana zahtjevima istine, pravednosti i općega dobra, nadahnuta naravnim zakonom, upisanim u ljudsku savjest vezanu božanskim zakonom. U enciklici Sapientiae Christianae (1890., br. 10.) snažno naglašava dužnost pokoravanja savjesti zbog njezine refleksije i participacije na božanskom zakonu. U enciklici Libertas (1888., br. 7.) izjavljuje da se smatra sretnim i ponosnim u opredijeljenosti za dobro slijeđenjem savjesti. Pio XI. u svom pismu, upućenom talijanskom episkopatu, Non abbiamo bisogno (1931., br. 56 - 59.) sugerira priziv savjesti kako bi se očuvao Božji zakon u Crkvi. Pio XII. u Summi pontificiatus (1939., br. 66.) afirmira nauk prethodnika u isticanju dostojanstva savjesti potičući državu da prizna pravo savjesti kao svete i nepogrješive. Ivan XXIII. izražava slično naučavanje u Ad Petri Cathedram (1959.) naglašavajući dužnost kršćana da žrtvuju osobna uvjerenja pokoravanjem crkvenom učiteljstvu. ${ }^{24}$

Ivan Pavao II. u enciklici Veritatis Splendor savjest predstavlja kao svetište čovjeka, glas Boga u čovjeku, govori o praktičnom sudu koji primjenjuje zakon, o obvezi koja ne dolazi od čovjeka, nego od Boga tako da savjest ispunjava ulogu bliže norme osobne moralnosti, o tome da savjest nije svojevoljna odluka te poziva na vjernost savjesti, na njezino ispravno oblikovanje i usklađivanje s objektivnom isti-

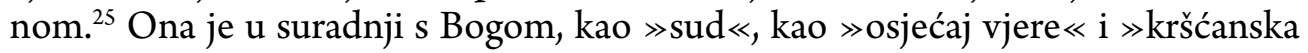
super-svijest «, » upravljenost prema vječnom božanstvu «. I u tim dimenzijama valja potražiti njezin identitet.

U enciklici Humanae vitae (1968.) poziva se na »ispravnu savjest « i dužnost poštovanja moralnoga zakona.

Drugi vatikanski sabor u Pastoralnoj konstituciji o Crkvi u suvremenom svijetu Gaudium et spes ističe:

$\gg$ U dubini savjesti čovjek otkriva zakon koji on sam sebi ne daje ali kojemu se mora pokoravati. Taj glas, što ga uvijek poziva da ljubi i ćini dobro a izbjegava zlo, kad zatreba, jasno odzvanja u intimnosti našeg srca: čini ovo, a izbjegavaj ono. Čovjek naime ima u srcu zakon što mu ga je Bog upisao. U pokoravanju tom zakonu jest isto čovjekovo dostojanstvo, i po tom zakonu će mu suditi. Savjest je najskrovitija jezgra i svetište čovjeka, gdje je on sam s Bogom, čiji glas odzvanja u njegovoj nutrini. $\ll^{26}$

\footnotetext{
${ }^{24}$ Usp. A. R. LUSVARDI, The Law of Conscience. Catholic Teaching on Conscience from Leo XIII to John Paul II., u: Journal of Catholic Thought \& Culture, Logos 15(2012.)2, 13-41., 14-19., 21-22.

${ }^{25}$ IVAN PAVAO II., Veritatis splendor - Sjaj istine. Enciklika o nekim temeljnim pitanjima moralnog naučavanja Crkve, Zagreb, 1998. (= VS), br. 55, 58, 59, 60, 61.

${ }^{26}$ GS, br. 16.
} 
$\mathrm{Na}$ taj se način u savjesti međusobno isprepliću Božje djelovanje (poziv) i ljudsko djelovanje (čovjekov odgovor), tj. suradnja između Boga i čovjeka. Time s pomoću savjesti čovjek otkriva dubinu i visinu svoje bogoličnosti, vrijednosti i dostojanstva. ${ }^{27}$ Moralna ili ćudoredna savjest označava čovjeka kao moralni subjekt svjestan dobrote ili zloće svojih činova na temelju ispravnoga suda razuma. Stoga Dignitas humanae potiče da:

>svatko ima dužnost, a potom i pravo, tražiti istinu u vjerskoj stvari, da sebi, upotrijebivši prikladna sredstva, razborito izgradi ispravne i istinite sudove savjesti koje čovjek prima posredstvom Božanskog zakona u savjesti. Nju mora vjerno slijediti u svom djelovanju, da dođe do Boga, svog cilja. $\ll^{28}$

Iako prema nauci Drugoga vatikanskoga sabora savjest nazivamo »Božjim glasom «, to ipak ne znači da Bog u svakom doživljaju savjesti jasno diktira što u konkretnom slučaju treba činiti. Savjest nije dana gotova, jednom zauvijek. Što je pak u konkretnom slučaju dobro, a što zlo i u kojoj mjeri, uvelike ovisi o ispravnom oblikovanju suda savjesti. ${ }^{29}$ Stoga su kršćani dužni slijediti diktate savjesti, ali su i odgovorni za formiranje dobre savjesti. To zahtijeva ozbiljno obrazovanje i promišljanje o sadržaju službenih crkvenih učenja ${ }^{30}$ i nadahnuća Duha Svetoga. Važno je da čovjek iskreno formira sudove svoje savjesti i slijedi ih i tako svoje pojedinačne izbore stavi u službu svoje temeljne opredijeljenosti.

\section{Sud savjesti}

Katekizam Katoličke Crkve donosi definiciju prema kojoj je moralna savjest »sud razuma po kojem ljudska osoba prepoznaje ćudorednu kakvoću nekog konkretnog čina što ga kani izvršiti, što ga vrši ili ga je već izvršila «. ${ }^{31}$

Dostojanstvenost moralnoga djelovanja ostvaruje se na ispravnom formiranju suda savjesti kako bi se slobodno i odgovorno postupalo, a da bi se djelovalo u skladu sa savješću, moralni čin mora biti duboko motiviran dobrom. ${ }^{32}$

${ }^{27}$ Usp. T. MATULIĆ, Oblikovanje identiteta bioetičke discipline. Etička svijest odgovornosti za opstanak u budućnosti, Zagreb, 2006., 105.

${ }^{28}$ DRUGI VATIKANSKI KONCIL, Deklaracija o vjerskoj slobodi »Dignitatis humanae $\ll, \mathrm{u}$ : ISTI, Dokumenti, Zagreb, 2002. (= DH), br. 3.

${ }^{29}$ Usp. V. POZAIĆ, Zrela savjest, u: Obnovljeni život 43(1988.)6, 503-515., 505.

${ }^{30}$ Usp. E. D. PELLEGRINO, The Physician's conscience, conscience clauses and religious belief: a catholic perspective, u: Fordham Urban Law Journal 30(2002.) 1, 221-244., 227.

${ }^{31}$ Katekizam Katoličke Crkve, Zagreb, 1994. (= KKC), br. 1788.

${ }^{32}$ Usp. D. S. ODERBERG, The Structure and Content of the Good, u: D. S. ODERBERG, T. CHAPPELL (ur.), Human Values: New essays on Ethics and Natural Law, Houndmills, 2004., 127-164. 
Prva razina u tom ostvarenju obuhvaća temeljnu savjest koja podrazumijeva moralno načelo: dobro čini, a zlo izbjegavaj. Druga razina jest moralna savjest, koja predstavlja konkretizaciju i personalizaciju sveukupnih moralnih činova s obzirom na čovjekovu temeljnu opredijeljenost. ${ }^{33}$ Tako sud savjesti potvrđuje sukladnost određenoga konkretnoga ponašanja sa zakonom; on oblikuje najbližu normu moralnosti nekoga voljnoga čina, ostvarujući primjenu objektivnoga zakona na pojedinačan slučaj. ${ }^{34}$

Sud savjesti može se razlikovati prema vrstama savjesti (savladiva i/ili nesavladiva pogrješna savjest, skrupulozna savjest, raspuštena savjest, laksna, sumnjičava, perfleksna, zrela savjest). Kršćanska tradicija pritom govori o trima uvjetima koji su potrebni kako bi savjest bila norma moralnosti: ispravnost - istinitost - sigurnost. ${ }^{35}$ Tom se odredbom nadalje definiraju elementi savjesnoga postupanja ${ }^{36}$ : znanje o dobru i njegovo prihvaćanje (objektivni moralni red); svijest dužnosti ostvarenja dobra i njegovo prihvaćanje (subjektivni moralni red; prosudba o konkretnom dobru ili zlu, razlikovanje i konkretiziranje toga dobra (moralni sud) i sankcioniranje učinjenoga djela (moralna presuda).

Za provedbu tih integralnih elemenata potreban je ispravno oblikovan odgoj savjesti.

\section{Oblikovanje i odgoj savjesti}

Budući da savjest prožima cijeloga čovjeka kao osobu, njegove moći, sposobnosti i djelatnosti, prema tomu odgajati savjest znači oblikovati sve naravne i nadnaravne moći čovjeka, njegovu osobnost i odnose prema sebi, bližnjemu i prema Bogu. Odgajati savjest zapravo znači odgajati čovjeka i kršćanina u najeminentnijem smislu te riječi. ${ }^{37}$

S obzirom na to da ona predstavlja i tvori temeljnu sposobnost cijeloga čovjeka, onda je i odgoj savjesti omogućen jedino odgojem cjelokupne osobnosti te zahtijeva neprekidno i svestrano (društveno, kulturno, psihološko, filozofsko, teološko, religiozno... $)^{38}$ odgajanje pojedinca tijekom cijeloga života kako bi postigao puninu

\footnotetext{
${ }^{33}$ Usp. M. SRAKIĆ, Moja je savjest čista, Đakovo, 2013., 179.

${ }^{34}$ Usp. VS, br. 59.

${ }^{35}$ Usp. M. VIDAL, Kršćanska etika, 104-105.

${ }^{36}$ Usp. Ž. BEZIĆ, Etika i život, Đakovo, 1995., 21., 26.

${ }^{37}$ Usp. Š. ŠIPIĆ, Savjest i sakrament pokore, u: Bogoslovska smotra 47(1977.)2-3, 276-290., 283.; A. BENVIN, Odgoj i rast savjesti, u: Bogoslovska smotra 47(1977.)2-3, 291-296.; P. ŠOLIĆ, Odgoj kršćanske savjesti, u: Crkva u svijetu 17(1982.)3, 210-219.

${ }^{38}$ Usp. I. ŠESTAK, Prilozi filozofiji o čovjeku, Zagreb, 2011., 93-98.
} 
kršćanske zrelosti, moralne ispravnosti u očitovanju ispravnih sudova i pravih vrijednosnih odluka te cjelovitu odgovornost prema sebi i drugima.

Da bismo mogli postupati savjesno, osim na temelju naravnoga zakona upisanoga u našu nutrinu, potrebno je također poznavati i moralna načela praktičnoga razuma vođenoga mudrošću i moralnim krjepostima, artikuliranima naukom crkvenoga učiteljstva. U skladu s tim Katekizam Katoličke Crkve potiče odgoj savjesti kako bi bila ispravna $\mathrm{i}$ istinita.

»Odgoj savjesti je zadatak cijelog života. On od prvih godina uvodi dijete u spoznaju i vršenje nutarnjeg zakona što ga prepoznaje moralnom savješću. Razborit odgoj uči kreposti; liječi od straha, sebičnosti i oholosti, od krivog osjećaja krivnje i pokreta samodopadnosti koji se rađaju iz slabosti i ljudskih pogrešaka. Odgoj savjesti jamči slobodu i rađa mir u srcu. $\ll 39$

Pri tome mu na raspolaganju stoje sredstva moralne spoznaje, ponajprije razum prosvijetljen vjerom i volja pomognuta milošću da bi se obdržavao moralni zakon. To zahtijeva da njihovo vanjsko ponašanje bude u skladu s unutarnjim diktatima njihove savjesti o tome što činiti u skladu s božanskim počelom u sebi i s vanjskim, društvenim normama.

$\mathrm{Na}$ tragu toga papa Ivan Pavao II. u enciklici Evanđelje života ističe kako bi (građanski) zakon trebao biti utemeljen na poštovanju temeljnih vrjednota, moralnoga reda i na općem dobru.

»Temeljne vrijednosti su dostojanstvo svake ljudske osobe, poštivanje njezinih nedodirljivih i neotuđivih prava, također i uzdizanje općeg dobra kao cilja i kriterija ravnanja političkog života. $\mathrm{Na}$ temelju tih vrijednosti ne mogu biti provizorne i promjenjive 'većine' mišljenja, nego samo priznavanje objektivnog moralnog zakona koji je, kao 'naravni zakon' upisan u srce čovječje, uporišna normativna točka samog civilnog zakona. $\ll^{40}$

U slučaju njihova razilaženja dolazimo do prigovora/neposluha/objekcije savjesti.

\section{Priziv savjesti u međunarodnim pravnim dokumentima}

Savjest igra veliku ulogu u moralnom obdržavanju osobnoga, vjerničkoga i profesionalnoga života, napose kada se sučeljavamo s odlukama koje prosuđuju i preispituju naše moralne dužnosti i odgovornost djelovanja u pojedinim slučajevima.

\footnotetext{
${ }^{39}$ KKC, br. 1784.

${ }^{40}$ IVAN PAVAO II., Evangelium vitae - Evandelje života. Enciklika o vrijednosti i nepovredivosti ljudskog života, Zagreb, 2003. (= EV), br. 70.
} 
Institut priziva savjesti utemeljen je na postavci da osoba ne mora poštovati građanski zakon ili neke njegove odrednice koje naređuju postupanje suprotno vlastitoj savjesti. Razlog takvog odbijanja leži u osobnoj savjesti, odnosno u vjerskim, moralnim i filozofskim uvjerenjima osobe. Najčešće je čin prigovora savjesti odgovor na sukob ili dvojbu u kojoj neka osoba osjeća obvezu dviju ili više etičkih odredbi od kojih se nijedna ne može zadovoljiti bez zapostavljanja ili odbacivanja druge. ${ }^{41}$

Priziv bi savjesti trebao biti osobno opravdanje prizivaču u nepostupanju, nesudjelovanju, neprihvaćanju mogućih raznih profesionalnih zahvata, poslova i načina djelovanja, ${ }^{42}$ koje proklamiraju brojni međunarodni dokumenti.

Nastanak instituta priziva savjesti kao ljudskoga prava možemo promatrati u širem kontekstu rađanja moderne doktrine ljudskih prava od druge polovice 20. stoljeća. On proizlazi iz prava na slobodu mišljenja, savjest i religijskoga ili drugoga uvjerenja te prava na autonomiju, identitet, privatnost i dostojanstvo osobe. Ta prava postaju priznata u mnogim pravnim aktima te profesionalnim i etičkim strukovnim kodeksima na međunarodnoj razini.

Sloboda mišljenja, savjesti i vjeroispovijesti spada u ljudska prava i temeljne slobode zajamčene međunarodnim dokumentima, u prvom redu Općom deklaracijom o ljudskim pravima, u kojoj se ističe: »Sva su ljudska bića rođena slobodna i jednaka u dostojanstvu i pravima. Obdarena su razumom i savješću te prema drugima trebaju djelovati u duhu bratstva. $\ll{ }^{43} \mathrm{Na}$ isti način o slobodi savjesti govori i Konvencija za zaštitu ljudskih prava i temeljnih sloboda ${ }^{44}$ te Međunarodni pakt o građanskim i politickim pravima (čl. 18, 1). ${ }^{45}$ Povelja temeljnih prava Europske unije zastupa slobodu

${ }^{41}$ Usp. Prigovor savjesti, u: M. GLAZIER, M. K. HELLWIG (ur.), Suvremena katolička enciklopedija, Split, 1998., 777.

${ }^{42}$ Usp. V. MILIČIĆ, Deontologija profesije liječnik - život čovjeka i integritet liječnika - ćudoredna raskrižja bioetike, Zagreb, 1996., 38.

${ }^{43}$ UJEDINJENI NARODI, Opća deklaracija o ljudskim pravima, Rezolucija br. 217/III (10. prosinca 1948.). Dostupno na: http://www.pariter.hr/wp-content/uploads/2014/10/opca_deklaracija_o_ ljudskim-pravima.pdf. čl.18. (22. 2. 2019.)

${ }^{44}$ VIJEĆE EUROPE, (Europska) Konvencija za zaštitu ljudskih prava i temeljnih sloboda (4. studenoga 1950.). Dostupno na: http://www.zakon.hr/z/364/(Europska)-Konvencija-za-za\%C5\%A1tituljudskih-prava-i-temeljnih-sloboda. čl.9. (22. 2. 2019.)

${ }^{45}$ Dostupno na: https://pravosudje.gov.hr/UserDocsImages/dokumenti/Pravo\%20na\%20pristup\% 20informacijama/Zakoni\%20i\%20ostali\%20propisi/UN\%20konvencije/Medjunarodni_pakt_o_ gradjanskim_i_politickim_pravima_HR.pdf (22.2.2019.) 
mišljenja, savjesti i vjeroispovijesti... Priznaje i pravo na prigovor savjesti. ${ }^{46}$ I Ustav Republike Hrvatske »jamči slobodu savjesti ${ }^{4}{ }^{47}$

I u crkvenim smo krugovima česti svjedoci pozivanja na pravo prigovora savjesti. Sjetimo se samo nedavnih, npr. kada je Benedikt XVI., obraćajući se na Međunarodnom kongresu katoličkih farmaceuta, poticao na zalaganje oko priznanja prava na priziv savjesti: $\gg N a$ moralnom području vaša je udruga pozvana suočiti se $s$ prigovorom savjesti, pravom koje treba biti priznato u vašoj profesiji kako bi vam se dozvoljavalo da, na direktni ili indirektni način, ne surađujete u nabavci onih sredstava čija je svrha ostvarenje nemoralnih ciljeva. $\ll{ }^{48}$ I papa Franjo djelatnike zdravstvenih ustanova podsjeća na moralnu obvezu prigovora savjesti. ${ }^{49}$

Komisija Hrvatske biskupske konferencije Iustitia et pax objavila je važnu izjavu o prigovoru savjesti u društvu i politici Savjest - čuvar čovjekovog dostojanstva i slobode $e^{50}$ u kojoj se analizira nepoštivanje demokratskoga društva i njegova pravnoga poretka kad je u pitanju uvažavanje slobode savjesti i osporavanje građanskoga prava na slobodno izjašnjavanje o nekim društveno-političkim i svjetonazorskim pitanjima. Smatra da je nepoštivanje osobne savjesti i njezina uvjerenja nedopustiv pokušaj ugrožavanja ljudske slobode, a time neposredno i ljudskoga dostojanstva. Osvješćuju se države da imaju obvezu poštovati pravo na priziv savjesti svakoga pojedinca, i odgovarajućim zakonodavstvom i oblikovanjem politika koje moraju poticati slobodu očitovanja savjesti.

U tom kontekstu poziva se i na poštovanje biopravnih dokumenata u zdravstvenim etičkim i strukovno-profesionalnim kodeksima.

\section{Priziv savjesti u kodeksima medicinske deontologije}

Od samih početaka, prije svega zbog specifičnosti usmjerenja na služenje ljudskom životu u njegovoj cjelovitosti, medicina nužno pred liječnike postavlja određene etičke imperative $\mathrm{i}$ jasne moralne obveze.

${ }^{46}$ Vidi na: https://eur-lex.europa.eu/legal-content/HR/TXT/?uri=celex\%3A12007P X čl.10. (22. 2. 2019.)

${ }^{47}$ Ustav Republike Hrvatske, u: Narodne novine 85/10., čl. 40.

${ }^{48}$ BENEDIKT XVI., Discorso al Convegno Internazionale dei famacisti cattolici. Dostupno na: http:// www.vatican.va/content/benedict-xvi/it/speeches/2007/october/documents/hf_ben-xvi_ spe_20071029_catholic-pharmacists.html (22.2.2019.)

${ }^{49}$ FRANJO, Amoris Laetitia - Radost ljubavi. Posinodalna apostolska pobudnica biskupima, prezbiterima i đakonima, posvećenim osobama, kršćanskim supruzima i svim vjernicima laicima o ljubavi u obitelji, 2016., br. 82 .

${ }^{50}$ Dostupno na: https://bitno.net/vijesti/hrvatska/savjest-cuvar-covjekovog-dostojanstva-i-slobode-izjava-o-savjesti/ (22. 2. 2019.) 
Ženevska deklaracija jasno zahtijeva od svojih djelatnika svečanu prisegu da će: »Apsolutno poštovati ljudski život od samog začetka. Niti pod prijetnjom neću dopustiti da se iskoriste moja znanja suprotno zakonima humanosti. ${ }^{51}$ I Konvencija o zaštiti ljudskih prava i dostojanstva ljudskog bića u pogledu primjene biologije i medicine: Konvencija o ljudskim pravima i biomedicini ${ }^{52}$ navodi da je svrha te Konvencije »štititi dostojanstvo i identitet svih ljudskih bića, bez diskriminacije, poštovanje njihova integriteta i drugih prava i temeljnih sloboda u pogledu primjene biologije i medicine «. U tome kontekstu omogućena je pravna mogućnost priziva savjesti u širem zdravstvenom djelovanju.

»S pravnoga stajališta priziv savjesti način je nepoštovanja zakona i način zaštite individualne slobode. To je i građansko pravo, ali i pravo liječnika i ostalih zdravstvenih djelatnika da odbiju sudjelovati u znanstvenim istraživanjima, dijagnostičkim i terapijskim postupcima i zahvatima ako se ti postupci i njihove svrhe, te kolateralni učinci, kose s njihovom savješću. ${ }^{53}$

Priziv savjesti u medicini možemo pratiti još od najranijih vremena etičke kodifikacije medicinske etike. ${ }^{54}$ Ono određuje pravo zdravstvenoga radnika da odbije pružiti medicinsku uslugu pod određenim, jasno definiranim uvjetima.

U Zakonu o liječništvu donosi se odredba o mogućnosti priziva savjesti.

$\gg$ Radi svojih etičkih, vjerskih ili moralnih nazora, odnosno uvjerenja liječnik se ima pravo pozvati na priziv savjesti te odbiti provođenje dijagnostike, liječenja i rehabilitacije pacijenta, ako se to ne kosi s pravilima struke te ako time ne uzrokuje trajne posljedice za zdravlje ili ne ugrozi život pacijenta. $\ll 55$

Kodeks medicinske etike i deontologije navodi:

»Liječnik ima pravo na priziv savjesti ako time ne uzrokuje trajne posljedice za zdravlje ili ne ugrozi život pacijenta. $\mathrm{O}$ svojoj odluci mora pravodobno obavijestiti pacijenta te ga uputiti drugom liječniku iste struke. $\ll^{56}$

\footnotetext{
${ }^{51}$ Dostupna u: N. ZURAK (ur.), Medicinska etika, Zagreb, 2007., 266-267.

${ }^{52}$ VIJEĆE EUROPE, Konvencija o zaštiti ljudskih prava i dostojanstva ljudskog bića u pogledu primjene biologije i medicine: Konvencija o ljudskim pravima i biomedicini, u: N. ZURAK (ur.), Medicinska etika, 321-328.

${ }^{53}$ N. ZURAK, Savjest i priziv savjesti u medicinskoj znanosti i u liječničkoj praksi, 100.

${ }^{54}$ Usp. G. GAMBINO, A. G. SPAGNOLO, Conscientious Objection in the Codes of Bioethics. http://www.bioethics.sk/files/journal/2002-12.pdf (22. 2. 2019.)

${ }^{55}$ Zakon o liječništvu, u: Narodne novine 121/03, 117/08. čl. 20.

${ }^{56}$ Kodeks medicinske etike i deontologije. Dostupno na: https://www.hlk.hr/EasyEdit/UserFiles/3-kodeks-medicinske-etike-i-deontologije-procisceni-tekst.pdf. čl. 2., br. 15. (22. 2. 2019.)
} 
Zakonu o sestrinstvu također omogućava:

»Radi svojih etičkih, vjerskih ili moralnih nazora, odnosno uvjerenja medicinska sestra se ima pravo pozvati na priziv savjesti te odbiti provođenje zdravstvene/sestrinske njege ako se to ne kosi s pravilima struke te ako time ne uzrokuje trajne posljedice za zdravlje ili ne ugrozi život pacijenta.«

$\gg$ Medicinska sestra mora u što kraćem roku izvijestiti odgovornu ili nadređenu osobu, ako postoji bilo kakav prigovor savjesti bitan za obavljanje njene profesionalne djelatnosti. U tom slučaju ne smije prestati pružati zdravstvenu njegu, ako bi time uzrokovala trajne posljedice za zdravlje ili ugrozila život pacijenta. $\ll^{57}$

Etički kodeks primalja radi očuvanja dostojanstva i ugleda primaljstva navodi:

$\gg$ Primalja ima pravo na priziv savjesti ako time ne uzrokuje trajne posljedice za zdravlje ili ne ugrozi život pacijenta/-ice. O svojoj odluci mora pravodobno obavijestiti pacijenta/icu i uputiti ju drugoj primalji. $\ll^{58}$

Zakon o ljekarništvu ${ }^{59}$ donosi odredbu o obavljanju ljekarničke djelatnosti prema kojoj farmaceut ima pravo pozvati se na priziv savjesti ako to ne ugrožava život čovjeka pri traženju izdavanja lijeka.

Zakon o dentalnoj medicini potvrđuje:

»Radi svojih etičkih, vjerskih ili moralnih nazora, odnosno uvjerenja doktor stomatologije se ima pravo pozvati na priziv savjesti te odbiti provođenje dijagnostike, liječenja i rehabilitacije pacijenta, ako se to ne kosi s pravilima struke te ako time ne uzrokuje trajne posljedice za zdravlje ili ne ugrozi život pacijenta. O svojoj odluci mora pravovremeno izvijestiti pacijenta te ga uputiti drugom doktoru stomatologije iste struke. $\ll{ }^{60}$

Zakon o medicinskoj oplodnji afirmira: $\gg Z$ dravstveni radnici i nezdravstveni radnici koji bi trebali provesti ili sudjelovati u provođenju postupaka medicinske oplodnje imaju pravo pozvati se na priziv savjesti radi svojih etičkih, vjerskih ili moralnih nazora, odnosno uvjerenja te odbiti provođenje postupka medicinske oplodnje ili sudjelovanje u tom postupku. $\ll^{61}$

\footnotetext{
${ }^{57}$ Zakon o sestrinstvu, u: Narodne novine 121/03, 117/08, 57/11.

${ }^{58}$ Etički kodeks primalja, u: Narodne novine 120/08. čl. 2. 20.

${ }^{59}$ Zakon o ljekarništvu, u: Narodne novine 121/03. čl. 25.

${ }^{60}$ Zakon o dentalnoj medicini, u: Narodne novine 121/03. čl. 26.

${ }^{61}$ Zakon o medicinskoj oplodnji, u: Narodne novine 88/09. čl. 38.
} 
Osim hrvatskim zakonodavstvom ta su prava zajamčena i na međunarodnoj razini. Vijeće Europe poziva države članice EU-a da adekvatno reguliraju taj predmet u svom zdravstvenom zakonodavstvu. Tako je i Parlamentarna skupština Vijeća Europe Rezolucijom 1763 o pravu na priziv savjesti u medicini afirmirala da:

»niti jedna fizička ili pravna osoba neće biti podvrgnuta prisili, neće se držati odgovornom, niti će je se na bilo koji način diskriminirati ako odbije izvršiti, osigurati prostorije za izvršavanje, pomoći izvršavanju ili se sama podvrgnuti abortusu, izvršiti pobačaj ili eutanaziju, ili bilo koji drugi čin koji bi iz bilo kojeg razloga uzrokovao smrt ljudskog fetusa ili embrija. ${ }^{62}$

Koncept priziva savjesti posebno je razvijen u literaturi moralne filozofije pod vidom naglašavanja nepovredivosti ljudskoga života i principa neškodljivosti, a potvrđen je i u brojnim zdravstvenim kodeksima.

Zakon o zdravstvenoj zaštiti (čl. 124.) tvrdi:

»Zdravstveni su radnici dužni kad pružaju zdravstvenu zaštitu poštovati moralna i etička načela zdravstvene struke, odnosno postupati prema pravilima zdravstvene struke, na način da svojim postupcima ne ugroze život i zdravlje ljudi. $\ll{ }^{63}$

Ljudsko dostojanstvo zahtijeva da ga se poštuje i u medicinskim intervencijama jer čovjek ima svoju nepovredivost i svetost. Ta vrijednost zahtijeva i od liječnika i od svakoga drugoga profesionalca da svaki život s kojim se susreće u svom pozivu/ djelovanju nastoji pripomoći, odbijajući time profesionalne činove koji se kose $s$ tim zahtjevom, njegovom savješću i moralnim i/ili etičkim uvjerenjem.

$\gg$ Prva i najneposrednija primjena tog nauka tiče se ljudskog zakona koji ne priznaje osnovno izvorno pravo života, vlastito pravo svakog čovjeka. Tako zakoni koji, s pobačajem i eutanazijom, ozakonjuju izravno ubojstvo nedužnih ljudskih bića, potpuno su i nepopravljivo suprotni nepovredivom pravu na život baš svih ljudi i prema tome niječu jednakost svih pred zakonom... Zakoni te vrste ne samo što ne stvaraju nikakvu obvezu u savjesti, nego prije pokreću tešku i preciznu obvezu da im se suprotstavi prigovor savjesti. $\ll^{64}$

\footnotetext{
${ }^{62}$ EUROPSKI PARLAMENT, Rezolucija VE 1763 (2010.) Parlamentarne skupštine Vijeća Europe o pravu na priziv savjesti $u$ medicini, stavak 1. Dostupno na: http://www.katolik.hr/wp-content/ uploads/2013/08/APCE-Rezolucija-1763-hrvatski-prijevod.pdf. čl.1. (22. 2. 2019.)

${ }^{63}$ Zakon o zdravstvenoj zaštiti, u: Narodne novine 150/08, 71/10, 139/10, 22/11, 84/11, 154/11, $12 / 12,35 / 12,70 / 12,144 / 12,82 / 13,159 / 13,22 / 14,154 / 14,70 / 16$.

${ }^{64} \mathrm{EV}$, br. $72 ; 73$.
} 
Iako je ljudski život nesumnjivo jedna od najviših vrjednota, zaštićena Ustavom i mnogim drugim međunarodnim propisima, vrijednost ljudskoga života nailazi na dosta relativizirano shvaćanje suvremenih etičkih paradigmi. Stoga ga je potrebno reafirmirati iz perspektive kršćanske antropologije.

\section{Vrijednost i dostojanstvo ljudskoga života u perspektivi kršćanske antropologije, moralne teologije i personalističke bioetike}

»Suvremeni čovjek suočen je sa sve brojnijim i složenijim moralnim dvojbama, a osobito onima koje se tiču ljudskoga života u njegovim najosjetljivijim razdobljima. Kako bi mogao ispravno djelovati, svakom je čovjeku darovana savjest koja mu služi kao moralni orijentir. $\ll{ }^{65}$

Međutim moralna svijest spram vrijednosti ljudskoga života upala je u određenu dvoznačnost. $S$ jedne strane ističe se vrijednost života, dok se s druge strane njegova vrijednost narušava. $U$ tehnološkoj civilizaciji sa životom se počelo postupati više kao s nekom objektivnom stvari, zato će naputak Donum vitae naglasiti da je život »dar, što ga je Bog Stvoritelj i Otac povjerio čovjeku, te od njega zahtijeva da bude svjestan njegove neizrecive vrijednosti i da za nj preuzme odgovornost $\ll{ }^{66}$

Bog je apsolutni Gospodar života, a čovjek kao stvorenje postavljen je u situaciju da život primi kao dar i odgovornom ga slobodnom čuva, štiti i promiče. ${ }^{67}$

»Ljudsko biće mora se poštivati i s njime valja postupati kao s osobom od samoga njegova začeća, pa mu se stoga od toga istoga časa moraju priznati prava osobe, među kojima je prije svega nepovredivo pravo svakoga nevinog ljudskog bića na život. ${ }^{68}$

I Naputak o nekim bioetičkim pitanjima Dignitas personae ističe da je:

$\gg$ Dostojanstvo ljudske osobe nužno priznati svakome ljudskom biću, od rođenja pa do prirodne smrti. To je temeljno načelo koje izriče veliko 'da' ljudskom životu, valja staviti u središte etičkog promišljanja nad biomedicinskim istraživanjima, koja u današnjem svijetu poprimaju sve veću važnost. ${ }^{69}$

\footnotetext{
${ }^{65}$ Poruka za Dan života 2019.

${ }^{66}$ KONGREGACIJA ZA NAUK VJERE, Donum vitae - Dar života. Naputak o poštivanju ljudskog života u nastanku i o dostojanstvu rađanja, Zagreb, 1997. (= DV), br. 7.

${ }^{67}$ Usp. M. VUGDELIJA, Čovjek i njegovo dostojanstvo u svjetlu Biblije i kršćanske teologije, Split, 2000., 284-285.

${ }^{68} \mathrm{DV}$, br. 1.

${ }^{69}$ KONGREGACIJA ZA NAUK VJERE, Dignitas personae - Dostojanstvo života Naputak o nekim bioetičkim pitanjima, Zagreb, 2009., br. 7.
} 
U skladu s tim zahtjevima Matulić ističe da $\gg$ biomedicinski i bioetički izazovi pred ljudskim životom zahtijevaju ponovno i kritičko promišljanje o svim relevantnim kriterijima glede zaštite i poštivanja vrijednosti fizičkog života $\ll .{ }^{70}$ Stoga mu je potrebno zaštititi njegovo dostojanstvo, svetost i nepovrjedivost argumentiranim činjenicama kršćanske antropologije, moralne teologije i personalističke bioetike.

U konfliktnim situacijama crkveno učiteljstvo od nas zahtijeva da branimo temeljne vrijednosti i temeljna ljudska prava, da promoviramo ljudski život. Ne samo da ih branimo, već pred nas ih predstavlja kao moralnu obligatornu dužnost. ${ }^{71}$ Priznavanje svetosti ljudskoga života i njegove beziznimne nepovrjedivosti nije mali problem ili pitanje koje se može držati relativnim u okviru pluralizma mišljenja prisutna u modernom društvu. »Kada u savjesti čovjek izgubi poštovanje prema ljudskom životu kao svetom, on nezaobilazno gubi i svoj identitet. $\ll^{72} \mathrm{U}$ skladu s tim papa Franjo povezuje prigovor savjesti s poštovanjem ljudskoga života: »Ako vas Hipokratova zakletva obvezuje da uvijek služite životu, evanđelje vas još više potiče, da ga uvijek i posvuda volite, ponajviše kada mu je potrebna osobita skrb (...) vjernost Evanđelju i poštovanje ljudskoga života ponekad traži hrabri izbor, a u nekim okolnostima i prigovor savjesti. $\ll^{73}$

U sintezi navedenoga potrebno je istaknuti nekoliko ključnih maksima.

Mi, kršćani, vjerujemo da naše ljudsko dostojanstvo izvire iz svojega počela, a to je sam Bog kao Stvoritelj, na kojega smo upućeni i s kojim smo povezani. Covjek je jedino biće koje je stvoreno na Božju sliku (Post 1, 26-28a), što za posljedicu ima posebno dostojanstvo. Ljudski se život dakle shvaća kao tajnovit odnos čovjeka s Bogom. ${ }^{74}$

»Ljudski je život svet jer od samog svog početka uključuje Božje stvaralačko djelovanje, i zauvijek ostaje u posebnom odnosu sa Stvoriteljem, svojom jedinom svrhom. Bog je jedini gospodar života od njegova početka do njegova svršetka: nitko i ni u kojim okolnostima ne može sebi uzeti pravo da izravno uništi nevino ljudsko biće. $\ll^{75}$

\footnotetext{
${ }^{70}$ T. MATULIĆ, Ljudski život u eri biomedicinskih i bioetičkih izazova, u: A. BOROVEČKI, S. OREŠKOVIĆ, S. BABIĆ-BOSANAC, Pravo na život. Priručnik iz izbornog predmeta iz područja medicinske etike koji se bavi pitanjima vezanim uz početak ljudskog života, Zagreb, 2015., 30-47., 47.

${ }^{71}$ Usp. D. TETTAMANZI, Nuova Bioetica cristiana, Casale Monferrato, 2000., 92-102.

${ }^{72}$ J. RATZINGER, Kršćanstvo i kriza kultura, Split, 2008., 47.

${ }^{73}$ FRANJO, Govor sudionicima kongresa talijanskih katoličkih liječnika u prigodi 70-e obljetnice. Dostupno na: http://www.ika.hr/index.php?prikaz=vijest\&ID=164838 (22. 2. 2019.)

${ }^{74}$ E. HAMEL, Biblijsko-teološke refleksije o ljudskim pravima, u: I. KOPREK (ur.), Ljudska prava čovjekovo dostojanstvo. Filozofsko-teološka promišljanja, Zagreb, 1999., 153.

${ }^{75} \mathrm{DV}$, br. 5.
} 
Svetost ljudskoga života ima korijen u Bogu koji je jedini svet. Prema tomu iz čovjekova suodnosa s Bogom zahtijeva se da se ljudski život smatra svetim i nepovrjedivim.

Konstitucija Gaudium et spes reći će da ideja o stvaranju čovjeka na sliku Božju poprima svoje pravo značenje i doseže savršenstvo u Kristu, savršenom čovjeku, slici Boga nevidljivoga $(\mathrm{Kol} \mathrm{1,15}),{ }^{76}$ otisku Bića njegova (Heb 1,3). ${ }^{77}$

Kršćanska antropologija ističe da je ljudski život vrijedan jer je temeljno, intrinzično, ljudsko dobro. Ontološki se stav vrijednosti osobe temelji na samoj ontološkoj strukturi ljudskoga bića. Čovjekova je objektivna vrijednost osobni bitak, a on je transcendentan i nedodirljiv, a ujedno time i normativan.

Pojam dostojanstva ljudske osobe potrebno je promatrati i kroz prizmu biblijskih izvješća koja naglašavaju integralnu antropologiju i holistički vid jedinstva duše i tijela, kao sjedište dostojanstva. Ljudski život nije samo tjelesnost, odvojena od duhovne komponente, već $\gg$ jedinstvo duše i tijela $\ll,{ }^{78}$ po kojem je čovjek biće, otvoreno transcendenciji i na temelju kojega ljudskoj osobi treba pristupati sa stavom njegove svetosti.

Kršćanski personalizam naglašava da je cijeli čovjek, duh i tijelo, jedinstven i da je kao takav Božje stvorenje i Bogu Stvoritelju odgovoran za razvoj svijeta i života. ${ }^{79}$

Nikakvo instrumentalizirano stanje osobnosti ne može umanjiti dostojanstvo čovjeka, a osobito ne može pretendirati da ljudski život nema vrijednost. Takvom funkcionalističkom poimanju suvremenih utilitarističkih etičkih pravaca trebalo bi se snažno oduprijeti objekcijom savjesti jer sam Bog upozorava: $\gg$ za vašu krv, za vaš život, tražit ću obračun.«Z Zbog toga biblijska zapovijed »ne ubij! $($ Izl 20,13) ima presudnu poruku za zdravorazumsko prosuđivanje ljudskoga djelovanja prema ljudskomu fizičkomu životu. ${ }^{80}$

Pio XII. u skladu s tim potiče da je: » bitni zadatak svake javne vlasti čuvanje nepovredivosti prava ljudske osobe $\ldots \ll{ }^{81}$ Ljudska prava svoj posljednji izvor nemaju u

\footnotetext{
${ }^{76} \mathrm{GS}$, br. 22.

${ }^{77}$ Usp. E. HAMEL, Biblijsko-teološke refleksije o ljudskim pravima, 153-171., 159.

${ }^{78}$ GS, br. 14.

${ }^{79}$ Usp. L. TOMAŠEVIĆ, Ontološko i funkcionalističko shvaćanje osobe: bioetička rasprava, u: Crkva u Svijetu 46(2011.)2, 143-170., 158.

${ }^{80}$ Usp. A. VUKASOVIĆ, Dostojanstvo ljudskog života, u: Obnovljeni život 51(1996.)6, 689-698., 695.

${ }^{81}$ I. KOPREK, Pravni poredak i postanak Opće deklaracije o ljudskim pravima, u: ISTI (ur.), Ljudska prava - čovjekovo dostojanstvo. Filozofsko-teološka promišljanja, Zagreb, 1999., 41.
} 
pukoj volji ljudskih bića, u državi, u javnim vlastima, nego u samome čovjeku i u Bogu, njegovu Stvoritelju. Ta su prava univerzalna, nepovrjediva, neotuđiva.

Ivan XXIII. u Pacem in terris započinje rekapituliranjem tradicionalnoga katoličkoga socijalnoga učenja o dostojanstvu ljudske osobe i poštovanju ljudskih prava. ${ }^{82}$ $\gg$ Temelj dobro uređene i plodonosne ljudske zajednice treba biti ono načelo da je svaki čovjek osoba, to jest da je narav obdarena razumom i slobodnom voljom. Ona sama po sebi ima prava i dužnosti što izravno i skupa proizlaze iz same njegove naravi. Budući da su oni općeniti i nepovredivi, ne mogu se ni na koji način otuđiti. ${ }^{83}$

Pavao VI. u sjedištu Ujedinjenih naroda progovorio je pred najuglednijim državnicima svijeta o njihovu promicanju ljudskih prava: »Ono što vi ovdje proklamirate jesu temeljna ljudska prava i dužnosti čovjeka, njegovo dostojanstvo i sloboda. Osjećamo da ste vi tumači onoga što je najuzvišenije u ljudskoj mudrosti, njezino obilježje svetosti. Život čovjeka je svet i nitko se ne smije usuditi u nj dirati.« ${ }^{84}$

Deklaracija Dignitatis humanae ističe kako »dostojanstvo ljudske osobe u ovo naše doba iz dana u dan sve više prodire u svijest ljudi, i raste broj onih koji zahtijevaju da ljudi mogu imati i služiti se vlastitom odlukom i odgovornom slobodom u svom djelovanju, ne pod pritiskom, nego svjesni svoje dužnosti $\ll .{ }^{85}$

Ivan Pavao II. u Evangelium vitae reći će da se društveni odnosi uređuju građanskim zakonima, a oni imaju zadaću osigurati opće dobro, priznati i braniti temeljna ljudska prava, promicati mir i javnu moralnost. ${ }^{86}$ Čovjekova sloboda nije neograničena i apsolutna, nego se on mora zaustaviti pred stablom dobra i zla jer je pozvan prihvatiti moralni zakon što ga Bog daje čovjeku. Zapravo, baš u tome prihvaćanju čovjekova sloboda nalazi svoje istinsko i potpuno ostvarenje. ${ }^{87} \gg$ Svaki je čovjek osoba, to jest da je narav obdarena razumom i slobodnom voljom. Ona samo po sebi ima prava i dužnosti što izravno i skupa izviru iz same njegove naravi. Budući

${ }^{82}$ Usp. Z. KUJUNDŽIJA, Dostojanstvo osobe i ljudska prava i slobode u naučavanju Ivana XXIII., Pavla VI. i Ivana Pavla VI., u: V. BLAŽEVIĆ (ur.), Ljudska prava i Katolička Crkva. Dostojanstvo osobe i temeljna ljudska prava u naučavanju Katoličke Crkve, Sarajevo, 2000., 268.

${ }^{83}$ IVAN XXIII., Pacem in terris - Mir u svijetu, enciklika, u: M. VALKOVIĆ (ur.), Sto godina katoličkog socijalnog nauka, Zagreb, 1991., 163.

${ }^{84}$ PAVAO VI., Govor pred Generalnom skupštinom Ujedinjenih naroda (4. listopada 1965.), u: M. VALKOVIĆ (ur.), Sto godina katoličkog socijalnog nauka, Zagreb, 1991., 312.

${ }^{85} \mathrm{DH}$, br. 1.

${ }^{86}$ Usp. I. JAKULJ, Neki etičko - pravni vidovi dostojanstva osobe u enciklikama Ivana Pavla II. i njegova zaštita u Zakonu kanonskog prava, u: I. KOPREK (ur.), Defensor hominis, zbornik radova na međunarodnom simpoziju «Čovjek u filozofiji K. Wojtyłe - Pape Ivana Pavla II.» održanog 5. travnja 2003. u Zagrebu, Zagreb, 2003., 97-117., 98-100.

${ }^{87}$ Usp. VS, br. 1161-1162. 
da su oni općeniti i nepovredivi, ne mogu se ni na koji način otuđiti. ${ }^{88}$ Poštovanje čovjeka kao osobe osnovni je zahtjev koji ne smije doći u diskusiju. O tome ovisi dostojanstvo, blagostanje i opstanak čovječanstva. ${ }^{89}$

Unatoč tomu što je među temeljnim ljudskim pravima zajamčeno pravo na priziv savjesti, nerijetko se susrećemo sa situacijama u kojima pravni poredak ne priznaje legitimnost prigovora savjesti.

\section{Nepoštovanje priziva savjesti i protupravna postupanja}

Pojedina osporavanja smatraju da bi olako korištenje pravima na priziv savjesti predstavljalo etičku i stručnu pogrješku te da bi moglo dovesti do štetnih posljedica za pacijenta, a samim time i do građanske, disciplinske, prekršajne i kaznene odgovornosti zdravstvenoga radnika. ${ }^{90}$

Da se to spriječi, zakon određuje stroge kautele prema kojima se priziv savjesti može poduzeti samo kada je taj zahtjev osnovan i kada nije u suprotnosti s pravilima struke te ako ne dovodi u pitanje pacijentovo zdravlje. Time priziv savjesti predstavlja ograničavajuću vrstu nužnoga zla općeprofesionalnoga djelovanja.

Motiv zbog kojega netko u određenom trenutku odbija ispuniti odredbu strukovnoga zakona mora biti $\gg \mathrm{u}$ ime $<$ vrijednosti koja je mnogo $\gg v i s ̌ a ~ «{ }^{91}$ te da pri tome pravo jednoga pojedinca ne ugrožava ili ne isključuje prava drugih ljudi. ${ }^{92}$

Pravo na priziv savjesti time nije apsolutno, već je podvrgnuto točno određenim ograničenjima te se na nj može pozvati iznimno. Ograničeno je u mjeri koju propisuju zakoni, nužni u demokratskom društvu, u interesu javne sigurnosti, zaštite javnoga reda, zdravlja ili morala, ili za zaštitu prava i sloboda drugih ljudi.

Papa Ivan Pavao II. pri obilježavanju prvoga Svjetskoga dana mira rekao je: $\gg$ Država ima dužnosti ne samo priznati temeljne slobode savjesti, nego ih promicati u svjetlu naravnog zakona i zahtjeva općeg dobra, sačuvavši poštivanje dostojanstva svakog čovjeka. Sloboda savjesti ne daje pravo na pretjeranu praksu prigovora savjesti. $\ll{ }^{93}$ Priziv savjesti treba biti ograničen ako: »nameće religijske ili druge

\footnotetext{
${ }^{88}$ IVAN XXIII., Pacem in terris, 165.

${ }^{89}$ Usp. L. TOMAŠEVIĆ, Ontološko i funkcionalističko shvaćanje osobe: bioetička rasprava, 164.

${ }^{90}$ Usp. T. BABIĆ, S. ROKSANDIĆ, Osnove zdravstvenog prava, Zagreb, 2006., 167.

${ }^{91}$ Usp. V. VALJAN, Bioetika, Sarajevo - Zagreb, 2004., 200.

${ }_{92}$ Usp. S. ŠEGVIĆ, Legitimnost građanskog otpora - neki teorijski aspekti, u: Zbornik radova Pravnog fakulteta u Splitu 44(2007.)2, 177-199.

${ }^{93}$ IVAN PAVAO II., Messaggio per la celebrazione della Giornata della pace (1. 1. 1991.). Dostupno na: http://w2.vatican.va/content/john-paul-ii/it/messages/peace/documents/hf_jp-ii_ mes_08121990_xxiv-world-day-for-peace.html (22.2.2019.)
} 
stavove pacijentu, utječe negativno na zdravlje pacijenta, ukoliko je zasnovan na pogrešnim znanstvenim interpretacijama ili predrasudama te ako proizvodi diskriminaciju i nejednakost.«

Neki protivnici prava na priziv savjesti predlažu da liječnici moraju odvojiti svoja osobna moralna uvjerenja od profesionalnoga života ako žele raditi u sekularnom društvu i ostati licencirani. Tvrde kako ta mogućnost u javnom zdravstvu dovodi do neučinkovitosti i nejednakosti, ugrožava kvalitetu i dostupnost zdravstvene usluge, da je nekompatibilna s liječničkim zanimanjem. Jedan od takvih zastupnika jest Julian Savulescu, koji smatra da liječnikova savjest ne bi nikada smjela interferirati s medicinskom praksom, smatrajući to povrjedom pacijentove autonomije i prava na samoodređenje. Stoga oni koji se ne mogu ograditi od toga ne bi ni trebali biti liječnici, a oni koji se pozivaju na objekciju savjesti, trebali biti disciplinirani. ${ }^{94}$

Drugi pak smatraju da liječnikova savjest ne bi trebala biti podređena zahtjevima pacijenata. ${ }^{95}$ Argument koji se navodi u korist priziva savjesti jest da bi se uskraćivanjem prava zdravstvenim radnicima na priziv savjesti ograničili etički, vjerski ili moralni nazori i uvjerenja zdravstvenih radnika i njihovo pravo zajamčeno međunarodnim konvencijama, Ustavom, zakonima, etičkim i deontološkim kodeksima. ${ }^{96}$ To nas dovodi do kolizije između liječničke autonomije i zahtjeva pacijenta i/ili društva.

\section{Prigovor savjesti između liječničke autonomije i zahtjeva pacijenata}

Kada govorimo o autonomiji u općenitom smislu, ona se ponajprije odnosi na samosvjesnost svakoga čovjeka koji ima pravo odlučivati o sebi jer je slobodno ljudsko biće.

Važno je naglasiti kako se istovremeno moraju poštovati i autonomija pacijenta i autonomija liječnika.

Usmjerimo li se na liječnikovu autonomiju, ona mu osigurava da u svom djelovanju samostalno procjenjuje i odlučuje kojim će se znanjem i tehnikama služiti u rješavanju problema u svom liječničkom djelovanju.

Prava liječnika štite i podupiru mnoge liječničke organizacije koje djeluju na području Europe i svijeta, Europski forum liječničkih udruga i Svjetske zdravstvene organizacije. Njihova uloga jest zaštititi autonomiju liječnika i brinuti se o zdravstvu.

\footnotetext{
${ }^{94}$ Usp. J. SAVULESCU, Conscientious objection in medicine, u: British Medical Journal (2006.)332, 294-297.

${ }^{95}$ Usp. J. K. DAVIS, Conscientius refusal and doctor's right to quit, u: Journal of Medicine and Philosophy 29(2004.) 1, 75-91.

${ }^{96}$ Usp. J. ČIZMIĆ, Pravo zdravstvenih radnika na »priziv savjesti $\ll, 783$.
} 
U Deklaraciji o liječničkoj autonomiji u 10. točki navode da liječnik mora imati strukovnu autonomiju da donosi kliničke odluke o skrbi pacijenta, ${ }^{97}$ napose Deklaracija o nezavisnosti i profesionalnoj slobodi liječnika.

$\gg$ U skrbi za svoje bolesnike liječnici moraju imati profesionalnu slobodu koju nitko ne smije ometati (dovoditi u pitanje). Treba čuvati i zaštititi izvršavanje profesionalne odluke liječnika (...) Liječnici moraju biti profesionalno neovisni u prikazivanju i obrani zdravstvenih interesa bolesnika (...) Osiguravanjem neovisnosti i slobode liječnika u obavljanju zdravstvene službe društvo osigurava najbolju moguću zdravstvenu skrb za svoje građane, koji pridonose održavanju snažnog i sigurnog društva. $\ll^{98}$

Boreći se za autonomiju liječnika, WMA je 2001. godine donijela Deklaraciju o pravima liječnika (2001.). Ona ima nadnacionalnu važnost i trebala bi obvezati svakog liječnika te ga istovremeno i štititi pred izazovima liječničkoga djelovanja i osporavanja njegovih prava, među kojima je i pravo na priziv savjesti. ${ }^{99}$

\section{Zaključak}

U mentalitetu pluralističkoga društva, kojemu pripadamo, susreću se različiti svjetonazori i ideologije: liberalizam, vrijednosni relativizam, individualizam, utilitarizam, praktični agnosticizam $\mathrm{i}$ ateizam, $\mathrm{u}$ kojem nužno nailazimo na radikalno razilaženje u shvaćanju čovjeka, kao i opasnu krizu moralnoga osjećanja, sve nesposobnijega razlikovati dobro i zlo, čak i kad je u pitanju temeljno pravo na život.

Stoga se u svem našem djelovanju, posebno onom povezanom $s$ dostojanstvom čovjeka, zahtijeva jak etički i moralni impuls kako bi se ostvarila istinska dobrobit čovjeka nad opasnostima koje mu prijete nekontroliranim biomedicinskim napretkom i liberalnim zakonitostima.

Moralna odgovornost pred samim sobom iziskuje djelovanje vlastite savjesti, posebice pred poštovanjem, obranom i čuvanjem ljudskoga života. To se može jedino ostvariti njegovom trajnom zaštitom, poštovanjem i nepovrjedivošću od samoga početka, kroz sve razvojne životne stadije, na svim društvenim, pravnim, kulturnim i medicinskim razinama.

S kršćanskoga stajališta moramo smatrati moralno neprihvatljivim pravne propise koje omogućuju brojne manipulacije ljudskim životom te kao katolici, zagovaratelji »kulture života«, moramo reagirati protiv njihove zakonske postojanosti i legalnosti.

${ }^{97}$ Usp. A. FRKOVIĆ, Bioetika u kliničkoj praksi, Zagreb, 2006., 178.

${ }^{98}$ Deklaracija svjetskog liječničkog udruženja o neovisnosti i profesionalnoj slobodi liječnika, u: N. ZURAK (ur.), Medicinska etika, 278.

${ }^{99}$ Usp. V. MILIČIĆ, Deontologija profesije liječnik, 44. 
Zadaća građanskoga zakona trebala bi biti osiguranje zajedničkoga dobra osoba priznavanjem i obranom temeljnih ljudskih prava. Nepriznavanje prava na život, zahvaljujući kojem društvo ima razlog svoga postojanja, proturječi mogućnosti da ostvari opće dobro. Stoga zakoni te vrste nisu samo upitne etičke već političke i ideološki naravi i zato nemaju nikakvu obvezu poštovanja i pokreću nužnost da im se suprotstavi prigovorom savjesti.

Savjest je participacija na božanskom zakonu i stoga je mjerilo moralnosti čovjekovih činova, ali i odgovornosti pred Bogom. Na tom tragu Ratzinger ističe da $\gg$ savjest mnogi shvaćaju kao neku vrstu pobožanstvenja subjektivnosti, uzdignutu na najviše mjerilo. Ona je jedini izvor moralne spoznaje, odnosno, osobna, iskonska spoznaja dobra i zla, koja se u pojedinačnom čovjeku pojavljuje kao izvor njegove sposobnosti da donosi moralne sudove $\ll .{ }^{100}$

Naš je zadatak da unaprjeđujemo razumijevanje moralnih zahtjeva unutar posebnih uvjeta našega vremena u kritičkom dijalogu s moralnim vrjednovanjima društva kako bismo pomogli Crkvi širiti apologetsku moralnu poruku u našem vremenu. Potom je potrebno naglašavati univerzalne etičke vrijednosti i na njima temeljiti općedruštvene zakone. To nas obvezuje da kao vjernici unosimo u političke, društvene, pravne i biomedicinske rasprave logiku objektivne istine o čovjeku i o vrijednosti njegova života.

$\gg$ Ono što nam je nadasve potrebno u ovom povijesnom trenutku jesu ljudi koji će, prosvjetljenom i proživljenom vjerom, učiniti Boga vjerodostojnim u ovome svijetu ... Potrebni su nam ljudi čiji će intelekt biti prosvjetljen Božjim svjetlom i kojima će Bog otvoriti srce kako bi njihov intelekt mogao progovoriti drugima, a njihovo srce moglo otvoriti srce drugih. $\ll^{101}$

Govoreći o savjesti u svjetlu suvremenih bioetičkih izazova, potičemo ponajprije vjernike, ali i sve ljude dobre volje da ne ustuknu pred tim izazovima, nego da još odlučnije promiču i štite ljudski život i njegovo neotuđivo dostojanstvo. Iznimno je važno da upravo vjernici prednjače u nastojanju življenja i djelovanja u skladu sa savješću osvjetljenom zakonom ljubavi prema Bogu i bližnjima, a osobito prema onima koji su nezaštićeni i koji se ne mogu zauzeti za svoja prava. Tako će vjernici u svojim sredinama svjedočiti o ljepoti i svetosti ljudskoga života u svim njegovim fazama i biti poticaj da i drugi počnu na taj način shvaćati i prihvaćati ljudski život. ${ }^{102}$ >Budimo narod života, jer nam je Bog u svojoj milosnoj ljubavi darovao Evanđelje života!«

(EV, br. 79)

\footnotetext{
${ }^{100}$ J. RATZINGER, O savjesti, Split, 2009., 66-67.

${ }^{101}$ Usp. J. RATZINGER, Kršćanstvo i kriza kultura, 40-41.

${ }^{102}$ Usp. HRVATSKA BISKUPSKA KONFERENCIJA, Poruka za dan života, Zagreb, 2019.
} 


\title{
CONSCIENCE AS GOD'S GIFT TO MAN IN THE CONTEXT OF THE CULTURE OF LIFE
}

\author{
Suzana VULETIĆ*
}

Summary: Conscience plays a major role in the moral observance of our personal, religious and professional lives. Being conscientious in the gifted freedom of action and moral responsibility of committing to act rightly in a conformist society with prevailing pluralistic bio/ethical beliefs, exposes us to many existential struggles to persevere in this conscientious conduct. This is especially evident in the application of numerous scientific advances in clinical practice, which opens a space for conflicting situations, by participating in scientific research, diagnostic and therapeutic procedures and interventions that are not in line with the moral conscience of the individual, where pragmatic goals conflict with medical ethics, the protection of human rights and dignity of life, which consequently requires: the preservation of conscientious commitment, the appeal of conscience. For the appeal of conscience to be morally grounded, it is necessary to become more familiar with the etymological and moral definition of conscience in the context of theological doctrine, to respect bio-legal determinants in ethical and professional principles that affirm the freedom of thought, conscience and religion as fundamental human rights, guaranteed by international documents and codes of medical ethics and deontology. Their joint initiatives support the moral responsibility of conscientious conduct which requires respect for the dignity, inviolability and sanctity of human life, which are particularly prominent in the perspective of Christian anthropology, moral theology and personalistic bioethics.

Keywords: conscience, natural law, formation of conscience, appeal of conscience, Christian anthropology, moral theology, personalistic bioethics, dignity, value/inviolability/ sanctity of life.

\footnotetext{
* Assoc. Prof. Suzana Vuletić, Ph. D., Catholic Faculty of Theology in Đakovo, J. J. Strossmayer University of Osijek, P. Preradovića 17,p.p. 54, 31400 Đakovo, Croatia, suzanavuletic007@gmail.com
} 